\title{
Planning for Raw Material Inventory Needs at PT. X Semarang With Min-Max Method
}

\author{
$1^{\text {st }}$ Jihan Pradesi, $2^{\text {nd }}$ Hendrik Cahya Prabowo \\ ${ }^{1.2}$ Universitas Selamat Sri Kendal, Indonesia \\ Email: jihan.pradesi@yahoo.com
}

\begin{abstract}
The main goal of each company is to optimize the company's profit because it will have an impact on business continuity and the most important element in achieving this goal is the existence of inventory in the form of goods. Then a good company is a company that has a good and neat system in terms of collecting data on the production of goods and their inventory. This study aims to determine the inventory of goods available in Company $X$ and improve the data input system at the company.
\end{abstract}

Keywords: Requirements planning, material inventory, raw materials, min-max method

\section{INTRODUCTION}

Inventory is a current activity that includes all goods belonging to the company with the intent and purpose of being able to be sold within a period or still in the company's production process or goods are ready to be used in production machines. both trading companies and manufacturing companies must always rely on inventory. Inventory as company assets, has an important role in business operations.

PT. X Semarang produces quality building iron products. Raw materials are imported from outside the company by suppliers. Scrap metal is also easy to find. The problem that often occurs is that raw materials come always late and production operators often work not according to the duties of each section because problems regarding this inventory will begin to arise when the company grows into a small and medium company, even into a large company. The existence of inventory will certainly be significant so that it requires special handling in order to continue to exist in running its business.

The min-max stock method is one of controlling raw materials which is divided into two levels, namely the minimum level and the maximum level. If the minimum and maximum levels have been set, it can minimize orders for raw materials if the inventory is too maximum. This is to avoid the amount of inventory can be too big or too small. The advantage of using this method is that you can find out the minimum to maximum inventory in the warehouse by arranging an inventory ordering plan according to the company's needs.

The application of the min-max method is able to make forecasts in the previous year, making the benchmark for the next year so that the warehouse can meet the total production capacity and the maximum stock of raw materials so that there is no waste of inventory costs. The application of the min-max method is intended to avoid too much inventory which can hamper the smooth production process.

\section{RESEARCH METHODS}

Inventories of raw materials or stored goods that can be used to meet certain purposes, such as generally used in the production or assembly process, can be resold if stock accumulates and is not used in the near future, can also be useful for spare parts of equipment or machinery. Let's say no company is able to operate without inventory, even though inventory is actually considered only a reserve of idle sources of funds, because before the inventory is used as its function means the funds tied up in it cannot be used for other purposes.

The concern here is the supply of raw materials. The availability of raw materials can affect the smoothness of the production process if there is a shortage of raw materials which results in the production process being temporarily stopped. The target is not achieved as well as the product results will be disrupted because it has not fulfilled the orders that have been requested by consumers. This is closely related to the declining level of sales because it makes consumers disappointed.

The company department is able to analyze inventory from various different sides. For example, the marketing department wants inventory levels to soar very high in order to serve customer demand as well as possible. The purchasing department tends to buy goods at once in very large quantities with the aim of getting discounts or rebates so that the unit price is lower. The production department does not want to be left behind by requiring a very large inventory level to avoid production bottlenecks due to a shortage of raw material stock. The finance department is the opposite of the marketing, purchasing and production departments. The finance department wants the lowest possible expenses and the highest possible income. 
International Journal of Computer and Information System (IJCIS)

Peer Reviewed - International Journal

Vol : Vol. 02, Issue 03, August 2021

e-ISSN : 2745-9659

https://ijcis.net/index.php/ijcis/index

Inventory management system can be defined as a series of control policies to determine the level of inventory that must be maintained and balanced. When inventory orders are held and when orders will increase and decrease. This system is able to determine and ensure the availability of the right inventory in the right quantity, quality and time.

Controlling the proper management of raw material inventory needs is not an easy thing. If the number of orders accumulates or is too large, it results in the emergence of large idle funds. Increasing storage costs and damage to goods from time to time are also greater. On the other hand, the lack of inventory indicates that the company is preparing to lose customers because it is unable to produce much. It often happens in every company that makes employees confused in finding goods.

Raw materials are the most important factors that help determine the level of cost of goods and the smooth production process. All companies that have a production process cannot be separated from the name of raw materials. With the raw materials, the company can easily meet the demands and needs of consumers. In addition, warehouses are needed to accommodate manufactured goods or raw material supplies for smooth production. Delays from the specified delivery time can harm the company because it is considered delayed and even consumers do not want to order goods anymore.

There are so many methods that can be used to find out the cause of an existing problem. One method is to use causal analysis with fishbone diagrams. Fishbone diagrams are often called Ishikawa diagrams or causeand-effect diagrams. Fishbone diagrams are a tool for identifying various potential causes of an effect or problem, and analyzing the problem through brainstorming sessions.

\section{RESULTS AND DISCUSSION}

The following is presented inventory data for 2019 and forecasts for raw materials in 2020 in the following table:

Table 1. Inventory Data

\begin{tabular}{|c|c|c|}
\hline Period & Demand (tons) & Forecast (tons) \\
\hline 1 & 100 & \\
\hline 2 & 150 & 200 \\
\hline 3 & 170 & 180 \\
\hline 4 & 180 & 160 \\
\hline 5 & 200 & 150 \\
\hline 6 & 210 & 190 \\
\hline 7 & 230 & 210 \\
\hline 8 & 200 & 230 \\
\hline 9 & 250 & 200 \\
\hline 10 & 250 & 190 \\
\hline
\end{tabular}

\begin{tabular}{|l|l|l|}
\hline 11 & 220 & 150 \\
\hline 12 & 180 & 150 \\
\hline 13 & & 150 \\
\hline
\end{tabular}

The following is the need for raw materials, usage and residual iron raw materials can be seen in the following table:

Table 2. Raw Materials

\begin{tabular}{|c|c|c|c|c|}
\hline Period & $\begin{array}{c}\text { Raw } \\
\text { material }\end{array}$ & $\begin{array}{c}\text { Amount of raw } \\
\text { material } \\
\text { requirement } \\
\text { (tons) }\end{array}$ & $\begin{array}{c}\text { Usage } \\
\text { (tons) }\end{array}$ & $\begin{array}{c}\text { Residual } \\
\text { (tons) }\end{array}$ \\
\hline 1 & Iron & 300 & 200 & 100 \\
\hline 2 & Iron & 400 & 400 & 0 \\
\hline 3 & Iron & 300 & 250 & 50 \\
\hline 4 & Iron & 320 & 250 & 70 \\
\hline 5 & Iron & 340 & 300 & 40 \\
\hline 6 & Iron & 310 & 300 & 10 \\
\hline 7 & Iron & 340 & 330 & 10 \\
\hline 8 & Iron & 370 & 300 & 70 \\
\hline 9 & Iron & 320 & 280 & 40 \\
\hline 10 & Iron & 280 & 200 & 80 \\
\hline 11 & Iron & 270 & 250 & 20 \\
\hline 12 & Iron & 150 & 120 & 30 \\
\hline \multicolumn{2}{|r|}{ Amount } & 3.700 & 3180 & 520 \\
\hline \multicolumn{2}{|c|}{ Average } & 308 & 265 & \\
\hline
\end{tabular}

Calculation of raw materials for iron products

Total inventory in $2019=($ total purchases-total usage $)+$ stock at the beginning of the year $=3,700-3,180+100$ $=625$ tons

Safety stock $=$ (maximum usage- average requirement $)$

$\mathrm{x}$ lead time $=(400-308) \times 1$

$$
=92 \text { tons }
$$

Minimum stock $=$ average requirement $\mathrm{x}$ lead time $)+$ safety stock $=(308 \times 1)+92$

$$
=400 \text { tons }
$$

Maximum stock $=2 \times$ (average lead time requirement)

+ safety stock $=(2 \times 308)+92$

$$
=708 \text { tons }
$$

Reorder rate $=$ Maximum-minimum

$$
\begin{aligned}
& =708-400 \\
& =308 \text { tons }
\end{aligned}
$$

Orders placed during one year $\mathrm{m}=\mathrm{D} / \mathrm{Q}$

$$
\begin{aligned}
& =3700 / 308 \\
& =12 \text { times }
\end{aligned}
$$

Costs used in inventory include material costs and inventory shortages. To find out the comparison of total costs using the min-max stock method.

a. Order fee

Telephone $=$ credit + wifi package and subscription

$$
=250,000 / \text { month }
$$$$
=3,000,000 / \text { year }
$$ 
International Journal of Computer and Information System (IJCIS)

Peer Reviewed - International Journal

Vol : Vol. 02, Issue 03, August 2021

e-ISSN : 2745-9659

https://ijcis.net/index.php/ijcis/index

Order administration

$\begin{array}{ll}\text { Note } & =120,000 \\ \text { Pen } & =30.000 \\ \text { Staples } & =30,000 \\ \text { Total } & =180,000\end{array}$

the total cost of ordering for one year is IDR $3,360,000$

b. Storage cost

capital cost $=1,000,000 /$ month

$$
=12,000,000 / \text { year }
$$

warehouse electricity cost

$$
\begin{aligned}
& =200,000 / \text { month } \\
& =2,400,000 / \text { year } \\
\text { Repair fee } & =1,500,000 / \text { month } \\
& =18,000,000 / \text { year }
\end{aligned}
$$

Total storage cost is IDR $32,400,000$

c. Transportation costs (costs for purchasing and shipping goods) $=1.000 .000 /$ month

total transportation cost for one year $=$ $12,000,000 /$ year

d. Inventory shortage cost

Additional admin fee $=100,000$ month

$=1.200 .000 /$ year

Cost of lost in sales $=10,000,000 /$ year

out of stock cost $=20,000,000 /$ year

total cost per year IDR 31,200,000

The total cost of inventory shortage for one year is IDR 78,960,000

Based on the data obtained on the theoretical basis, it is known the minimum, maximum, safety stock, and reorder level $(\mathrm{Q})$ of the raw materials to be produced. Below is a recap of the data calculations that can be seen as follows:

Table 3 Calculation of data

\begin{tabular}{|l|c|c|c|c|c|}
\hline $\begin{array}{c}\text { Raw } \\
\text { material }\end{array}$ & $\begin{array}{c}\text { End of 2019 } \\
\text { stock }\end{array}$ & $\begin{array}{c}\text { Safety } \\
\text { stock }\end{array}$ & $\begin{array}{c}\text { Minimum } \\
\text { stock }\end{array}$ & $\begin{array}{c}\text { Maksimum } \\
\text { stock }\end{array}$ & M \\
\hline Iron & 625 & 92 & 400 & 308 & 12 \\
\hline
\end{tabular}

The table above concludes that the stock at the end of 2019 at the company is very large when compared to the safety stock calculated using the min-max stock method. For this reason, the company may need to consider this method so that there are not too many available raw materials.
Table 4. Product Results

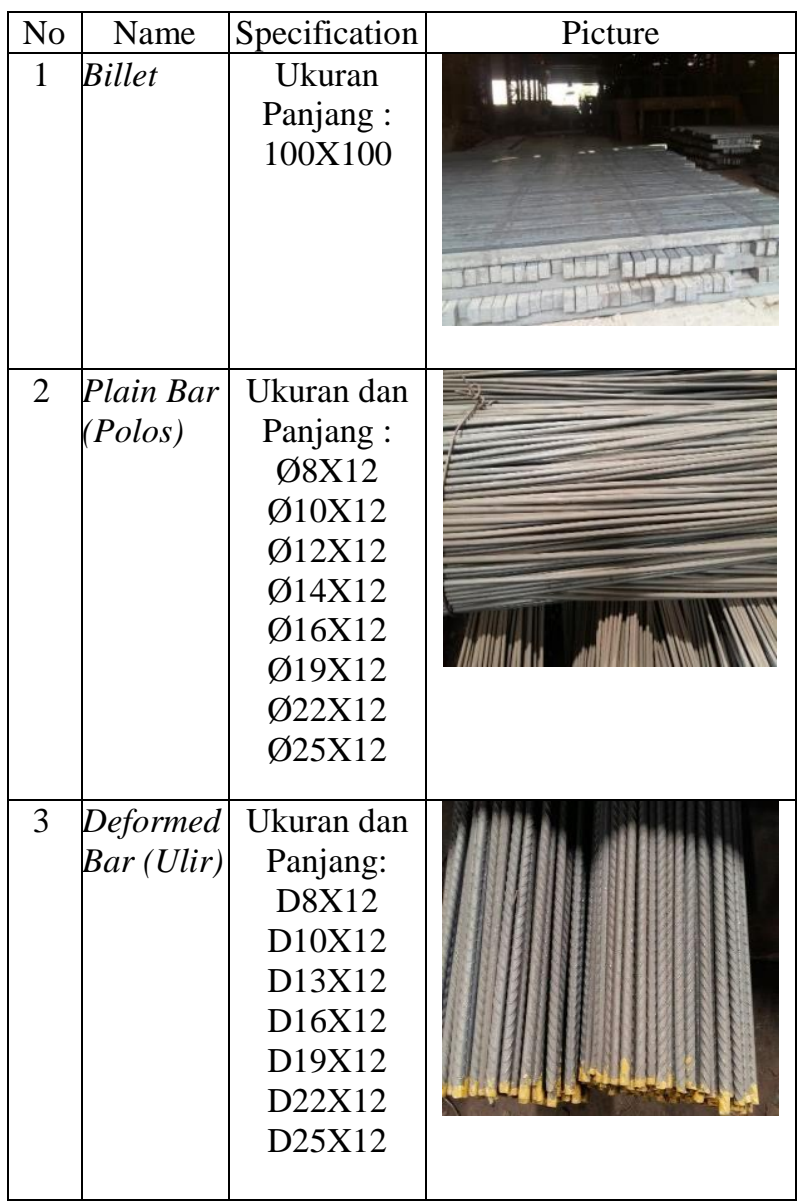

\section{CONCLUSIONS AND SUGGESTIONS}

\section{Conclusions}

With the raw material inventory already in the data, the company knows the shortage or excess stock. The application of the min-max method is intended to avoid too much inventory which can hamper the smooth production process. This method is an inventory control method that tries to answer all inventory problems including the safety stock that must exist, the minimum inventory policy, and the maximum inventory. By looking at the tobacco material stock report which shows that there is still a lot left in the warehouse, by using this method it is hoped that there will be no more accumulation of raw materials in the warehouse, and a minimum and maximum inventory policy that must be in the warehouse can be determined. This method is expected to make the company more efficient. effective and efficient in managing raw materials such as saving costs in the production process. For further research is expected to be able to get a more optimal savings for each period. In addition, it is expected to be able to find 
International Journal of Computer and Information System (IJCIS)

Peer Reviewed - International Journal

Vol : Vol. 02, Issue 03, August 2021

e-ISSN : 2745-9659

https://ijcis.net/index.php/ijcis/index

a formulation to obtain the optimal composition of inventory from each raw material needed by PT. X Semarang.

\section{Suggestions}

Suggestions from this research are as follows:

1. Ordering raw materials must be right so that there is no accumulation of goods because there is no warehouse expansion

2. Before going home, make sure to always take notes and check what items are needed

3. The company should always look at data from previous years so that the results obtained are more accurate for future purposes.

4. Inventory of raw materials must be maintained balance of incoming and outgoing goods

\section{REFERENCES}

[1] Aditiyana, Mochammad Iqbal. 2007. Pengendalian Bahan Baku Utama Menggunakan Metode MinMax Stock Pada Coffee Shop Di Yogyakarta Untuk Optimalisasi Persedian Bahan (Studi Kasus Di Maraville Yogyakarta).

[2] Harwan Ahyadi, Siti Khodijah. 2017.Analisis Pengendalian Persediaan Suku Cadang Pesawat B737-Ng Dengan Pendekatan Model Periodic Review Di Pt. X

[3] Abdus Salam, Mujiburrahman Mujiburrahman. 2018. Pengendalian Persediaan Bahan Baku Menggunakan Metode Min-Max Stock Pada Perusahaan Konveksi Gober Indo

[4] Cynara Kezia Yedida, Muhammad Mujiya Ulkhaq. 2017.Perencanaan Kebutuhan Persediaan Material Bahan Baku Pada Cv Endhigra Prima Dengan Metode Min-Max 